\title{
Conceptual modeling of geothermal waters in the continental rift zones of the Menderes Massif, western Anatolia, Turkey
}

\author{
NEVZAT ÖZGÜR \\ Suleyman Demirel University, Faculty of Engineering, \\ Department of Geological Engineering, 32260 Isparta, \\ Turkey \\ From Early to Middle Miocene, the \\ continental rift zones of Büyük Menderes, \\ Gediz, and Kücük Menderes within the \\ Menderes Massif, were formed by extensional \\ tectonic features, and are represented by a \\ great number of geothermal waters. \\ Geothermal waters are related to faults which \\ strike preferentially NW-SE and NE-SW and \\ locate diagonal to general strike of the rift \\ zones. These faults are probably generated by \\ the compressional tectonic stress, which leads \\ to the deformation of uplift between two \\ extensional rift zones. Geothermal waters of \\ Kizildere, Bayindir und Alaşehir represent \\ excellent examples. In the area, meteoric \\ waters percolate at fault zones and permeable \\ rocks where meteoric waters are heated by a \\ magmatic cooling and ascend to the surface \\ due to their density caused by convection \\ cells. The volatile components of $\mathrm{CO}_{2}, \mathrm{SO}_{2}$, \\ $\mathrm{HCl}, \mathrm{H}_{2} \mathrm{~S}, \mathrm{HB}, \mathrm{HF}$, and $\mathrm{He}$ from the magma \\ reach the geothermal water reservoir where an \\ equilibrium between altered rocks, gas \\ components, and geothermal waters \\ performed. These geothermal waters are \\ characterized by high $\mathrm{CO}_{2}, \mathrm{H}_{2} \mathrm{~S}$ and $\mathrm{NaCl}$ \\ contents. The geothermal waters are exploited \\ for various uses consequently, i.e. for \\ geothermal energy with a capacity of 1200 \\ MWe, balneology, and green houses.
}


